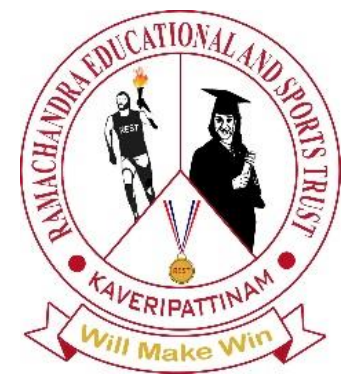

Recent trends in Management and Commerce

Vol: 2(1), 2021

REST Publisher

ISBN: 978-81-936097-6-7

Website: http://restpublisher.com/book-series/rmc/

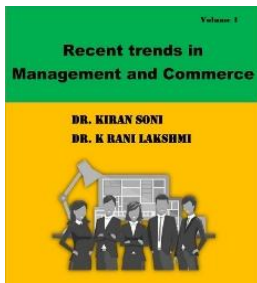

\title{
Payment Banks in India: A comprehensive Analysis
}

${ }^{1}$ Melby George, Dr. ${ }^{2}$ Anil P.V.

1. Research Scholar, Department of Commerce and Management studies, Kannur University

2. Assistant Professor, Department of commerce, Pazassi Raja NSS College, Mattanur, Kannur University

Corresponding Author: melbygeorge658@gmail.com

\begin{abstract}
One of the greatest difficulties facing the Indian economy today is the banking sector's non-inclusion in rural India. Any traditional bank would find it unprofitable to open a new branch in every village. A payments bank, as defined by the Reserve Bank of India, is a new type of bank that works on a smaller scale than a traditional bank and does not carry any credit risk. It can perform the majority of banking functions, but it cannot make loans or issue credit cards. The goal of establishing payments banks is to increase financial inclusion by providing small savings accounts and payments/remittance services to migratory workers, low-income families, small enterprises, other unorganised sector firms, and other users. Rather than having physical branches, these banks operate digitally (via mobile phones and other internet-connected devices). Through this study, the researcher is seeking to make a detailed investigation to the payment banks in India.
\end{abstract}

Key words: Payment banks, financial inclusion, revenue stream

\section{Introduction}

The Indian government wants its digital India plan to reach every Indian citizen. To realise the goal of digital India and to promote financial inclusion in the country, the Reserve Bank of India envisioned the notion of payments banks, which will boost financial service penetration by reaching regions where traditional banks cannot. The purpose is to give financial services to workers, low-income families, small enterprises, and others who do not have (or have restricted access to) them. Commercial banks' fundamental drawback is that they have a limited geographic reach. By opening a payments bank, this restriction is abolished. A payment bank is a public limited company that has been registered under the Companies Act of 2013 and has been granted a licence under Section 22 of the Banking Regulation Act of 1949 as well as a special authorization by the RBI to operate as a payments bank. Only 11 of the 41 companies that filed for a payments bank licence were granted. RBI took into account the company's network and reach as one of the most important elements. As a result, payment bank licences have been issued to companies that provide mobile telecommunications services, supermarket services, prepaid wallet services, and other similar services in order to serve consumers and small businesses who would otherwise have limited or no access to banks. Payments Banks will augment the potential of financial inclusion in the Indian economy. It will allow those citizens who have only transacted in cash, to head towards formal banking. Traditional banks may be reluctant to open branches in every village due to its uneconomic returns, but simple mobile phone coverage is all that is required now. India also serves as a big remittance market and with money transfers possible through mobile phones, workers and migrant labours could simply shift to Payments Bank and send their money home.

\section{Literature Review}

Thushara T.K. (2020) in the study "Role of Payment Banks in Financial Inclusion," argued that financial inclusion aims to remove the barriers that prevent people from participating in the financial sector and benefiting from its services. Payment banks' savings and remittance services are aimed at persons who live in rural regions or who have little or no bank access. Currently, the RBI has awarded licences to corporations that operate supermarket chains (with a significant distribution network), mobile operators (with a large client base), and postal services which tap in a large number of customers. . Because these firms have a wide distribution network or client base, they aid financial penetration by ensuring that financial and banking services are available to everyone in the country. This encourages citizens to save money. Dr. Prasanna Kumar T $\mathbf{M}$ and Mr.Arjun $\mathbf{J}$ (2020) in their study reveals that there are various RBI restrictions on this payment banks. Deposit collection for payments banks is capped at Rs 1 lakh per customer, and they are not allowed to lend. The money collected as deposits has to be parked in government securities and larger banks. Payments banks are proving to be nothing more than aggregators. Payment banks were established with the primary goal of boosting the effect of the financial inclusion movement. There are numerous bottlenecks that need to be addressed before the real benefits of payment banks. Hundreds of millions of Indians lack access to financial services. They are unable to get government benefits, loans, insurance and even interest on savings. Bhansali Shrey and Iyer Geeth (2018) investigated the views of various groups of the Indian people on the RBI and Government of India's payment banks initiative. Persons are aware of the payment banks being launched in our nation by the RBI, and the payment banks' target market, namely small company owners, migrant workers, and other people from low-income categories, are eager to utilise payment banks, according to the survey. According to Dr. G. Sabitha 
Srinivas (2017), opening a new branch in every village is unprofitable for any traditional bank. Payment banks offer every rural and urban citizen a low-cost platform for fundamental banking services. The domestic remittance market in India is worth around Rs. 900 billion. Payment banks are critical to realising the ideal of a cashless economy. In her article, the researcher determined that millions of Indians lack access to banking services. They are unable to access government advantages such as loans and insurance, as well as savings interest. The platform for accessing financial services will be provided by M- Banking, PMJDY, and IPPB. Dr. Reena Agarwal (2016) conducted research into the banking industry's present developments. The study's goal was to investigate the necessity for payment banks and their function in society, as well as to gain a better understanding of how they operate. Payment banks will bring a new digital approach to banking, according to the study, making banking faster and easier for customers.

\section{Objectives}

1. To investigate the emergence and operation of payment banks in India.

2. To make a comparative analysis of payment banks and commercial banks

3. To examine the revenue streams of payment banks in India.

\section{Research Methodology}

This paper is purely on conceptual study. The data and information collected from secondary sources like published articles, National and International Journals, Newspaper, websites etc.

\section{History of Payment Banks in India}

> 23 September 2013: The RBI formed a committee on comprehensive financial services for small business and lowincome households headed by Nachiket Mor.

$>7$ January 2014: Nachiket Mor committee submitted its final report with the various recommendations, it recommended for the formation of a new category of bank called the payment bank.

> 17 July 2014: The RBI issued the draft guidelines for the payment banks, inviting suggestions comments from interested entities and the general public.

$>27$ November 2014: RBI released final guidelines for payment banks.

$>$ February 2015: RBI released the list of entities which had applied for a payment banks license. There were 41 applicants. It also announced that an external advisory committee (EAC) headed by the Nachiket Mor would evaluate the license applications.

$>28$ February 2015: During presentation of the budget it was announced that Indian post will use its large networks to run the payment banks.

> 6 July 2015: The external advisory committee submitted findings. The applicant entities were examined for their financial track record and government issues.

> 19 August 2015: The RBI of India gave "in-principle" licenses to 11 entities to launch payment banks out of these 3 were surrendered. The remaining 8 entities are listed below:

- Aditya Biral Nuvo

- Airtle M commerce services

$>$ Department of posts

> FINO paytech

> National securities deposits

$>$ Reliance Industries

> Patym

- Vodafone M-pesa

RBI will grant full licenses under section 22 of banking regulation act, 1949, after it is satisfied that conditions have been fulfilled. List of the payment Banks in India that are currently active are:
$\checkmark \quad$ Airtel Payments Bank
$\checkmark$ Aditya Birla Payments Banks
$\checkmark$ India Post Payments Bank
$\checkmark$ Fino Payments Bank
$\checkmark$ Jio Payments Bank
$\checkmark$ Paytm Payments Banks.

\section{Payment banks provide the following services:}

* Acceptance of demand deposits;

- Individual customers must maintain a minimum balance of Rs. 1,00,000

* Issuance of ATM/Debit cards

- Credit cards cannot be issued.

* Remittance and payment services

* Issuing Pre-Paid Payment Instruments (PPIs)

* Internet banking - Serving as a business correspondent for other financial institutions

* Non-risk-sharing basic financial services operations such as mutual fund unit distribution, insurance products, pension products, and so on, with previous RBI clearance and after meeting the sectoral regulator's criteria 


\section{Payment banks are subject to the following restrictions}

* They are prohibited from engaging in lending activities such as advancing loans and issuing credit cards; and

* They must invest at least $75 \%$ of their "demand deposit balances" in government securities/Treasury Bills with maturities of up to one year in order to maintain their SLR.

* Hold a maximum of $25 \%$ in current and time/fixed deposits with other scheduled commercial banks for operational and liquidity management purposes

* have a paid-up equity capital of Rs. 100 cores

* maintain a minimum capital adequacy ratio of $15 \%$ of risk weighted assets (RWA)

* Tier I capital should be at least 7.5 per cent of RWAs.

* Tier II capital should be limited to maximum of 100 per cent of total Tier I capital

* should have a leverage ratio of not less than 3 per cent

\section{Difference between commercial banks and payment banks}

In India, both Payments Banks and Commercial Banks are governed by the Banking Regulation Act, 1949, although the functions of commercial banks and payments banks are vastly different. The following are the distinctions:

$\checkmark \quad$ The banking system in India is thought to have begun in 1786 with the foundation of the Bank of Calcutta, although the payments bank began operations in November 2017.

$\checkmark$ Commercial banks can take any amount as a deposit from a single customer, whereas payments banks are limited to a maximum balance of Rs. 1,00,000 per customer.

$\checkmark$ Payments banks can offer ATMs or debit cards to their account customers, but not credit cards, whereas commercial banks are exempt from this law.

$\checkmark$ A commercial bank's initial paid-up voting equity capital must be 500 crore rupees, whereas a payments bank's first paid-up equity capital must be Rs. 100 crore.

$\checkmark$ To distinguish themselves from other banks, payment banks must use the term "payments bank" in their name but commercial banks are not required to do so.

$\checkmark$ Payment banks must invest at least $75 \%$ of their total demand deposits in government securities having a one-year maturity term (known as the Statutory Liquidity Ratio), whereas commercial banks must invest no more than $22 \%$.

$\checkmark$ Payment banks are unable to provide loan services to the general public, whereas commercial banks rely only on loan services to generate revenue.

$\checkmark$ Payments banks are unable to take deposits from NRIs. It indicates that non-resident Indians (NRIs) who have settled abroad are unable to deposit money in payments banks, although commercial banks are able to take NRI deposits.

\section{Revenue stream of payment banks}

Payments banks, unlike commercial banks, do not make money by lending money. Payment banks, on the other hand, gain money through the following operations.

* Interest Arbitrage: A payments bank makes money by depositing money with another bank and/or government deposits that pay higher interest rates than the payments bank does. Companies that provide prepaid wallet services often achieve this by depositing funds into an escrow account at a partner bank.

* Transaction Costs: Payments banks charge consumers a portion of the transaction value as transaction costs. For example, if the transaction value is between ₹10 and 4,000, Airtel Payments bank charges ₹5-25, and if the transaction amount is beyond 4,000, 0.65 percent of the withdrawal amount is charged. Many additional services are also fee-based.

* Cross-Selling and Bank Correspondents: Payments bank cannot lend or open a subsidiary to lend money. Hence, they partner with other organisation to sell their products (insurance, investments, etc.) and make money with it. Payments banks also tie-up with existing banks to sell their loan services.

* POS And MDR: Just like commercial banks, payment banks make money as commissions from transactions through the point of sale terminals and resultant MDR (merchant discount rate).

\section{Conclusion}

Payment banks were established with the primary goal of boosting the effect of the financial inclusion movement. Payment banks are important in administering the government's direct benefit, transfer systems, in which subsidies for health care, education, and gas are transferred directly to recipients' accounts. The establishment of payments banks not only increases financial inclusion in the country, but it also strengthens the country's weaker sectors, allowing them to contribute to the country's economic development. However, the competition between other banks and payment banks will pave the path to expansion and improvement in quality of banking services are lowered prices and this may eventually result in financial inclusion. To get around the limitation of not being allowed to lend, they're stitching together a web of unconventional income sources, including data monetisation, cross-selling financial goods, constructing credit access platforms, and developing alternate merchant payment structures. The fundamental goal of the payments bank is to leverage technology and the internet to bring payment and financial services to small businesses, low-income households, and migratory workers. The payment bank allows for greater access to financial services in rural parts of the country. 
1. Thushara T.K (2020). Role of Payment Banks in Financial inclusion", International Journal of Emerging Technologies and Innovative Research (www.jetir.org), ISSN:2349-5162, Vol.7, Issue 12, page no.1273-1276, December-2020, Available :http://www.jetir.org/papers/JETIR2012162.pdf

2. Dr. Prasanna Kumar, T. M., \& Mr.Arjun, J. (2020). Role of Payments Banks in India. Mukt Shabd Journal (ISSN NO: 2347-3150), 9(11), 309-315.

3. Bhansali, S., Bhatt, T., Chhatwani, M., Deshpande, A., \& Iyer, G. (2018). Role of Payment Banks in India: Opportunities and Challenges. International Journal of Advances in Management and Economics (ISSN: 2278-3369), 7(1), 1-16.

4. Kokila, M. S. and Krishnan, Dr. S. Gokula, An Empirical Study on the Awareness and Usage of Payment Banks Among College Students in Bangalore City (February 28, 2019). International Journal of Research, Volume VIII, Issue II, February/2019 , Available at SSRN: https://ssrn.com/abstract=3349534 or http://dx.doi.org/10.2139/ssrn.3349534 https://www.managementjournal.info

5. https://www.rbi.org.in/Scripts/BS_PressReleaseDisplay.aspx?prid=32615

6. https://www.moneycontrol.com/news/business/economy/industrial-production-returns-to-contraction-in-januaryretail-inflation-at-3-month-high-in-february-6640751.html

7. https://www.thehindubusinessline.com/opinion/payment-banks-a-reality-check/article22612613.ece

8. https://economictimes.indiatimes.com/definition/Payments-banks

9. http://www.google.co.in/amp/s/fintrakk.com/payment-banks-in 